\title{
A COMPARATIVE ASSESSMENT OF SEEDLING SURVIVAL AND BIOMASS ACCUMULATION FOR FOURTEEN WETLAND PLANT SPECIES GROWN UNDER MINOR WATER-DEPTH DIFFERENCES
}

\author{
Lauchlan H. Fraser ${ }^{1,2}$ and Jason P. Karnezis ${ }^{1}$ \\ ${ }^{1}$ Department of Biology \\ University of Akron \\ Akron, Ohio, USA 44325-3908 \\ ${ }^{2}$ Present address: \\ Department of Natural Resource Science \\ Thompson Rivers University \\ Kamloops, British Columbia, Canada V2C $5 N 3$ \\ E-mail: lfraser@tru.ca
}

\begin{abstract}
The purpose of this experiment was to investigate the survival and biomass accumulation of wetland plant species under different water depths in controlled microcosms. In the greenhouse, two-weekold seedlings were randomly assigned to one of seven water-depth treatments $(-6,-4,-2,0,+2,+4$, and $+6 \mathrm{~cm}$ relative to the soil surface) and allowed to grow for six months. Species included five perennial sedges, four perennial and one annual grasses, and two perennial and two annual forbs. Twelve of the species had their lowest biomass and lowest survivorship at water depths greater than $0 \mathrm{~cm}$. The root:shoot ratio, however, did not change across water-depth treatments. Biomass accumulation differed by plant form (sedges $>$ forbs $>$ grasses). Annuals had the greatest biomass values across the widest range of water depths compared to perennials. Of the fourteen plants tested, Lythrum salicaria (purple loosestrife), one of the two invasive, non-native species tested, had the greatest biomass at water depths from -6 to +2 , whereas Phalaris arundinacea (reed canarygrass), the other invasive, had comparatively small mean biomass values. Ranking of biomass between species was highly concordant between non-flooded treatments but not significantly concordant between flooded treatments indicating that plant species have distinct responses to flooding. This research suggests that newly established plant seedlings in wetland restorations should not be submerged, or if submergence is unavoidable, annuals and sedges may be more tolerant of prolonged flooding.
\end{abstract}

Key Words: $\quad$ wetland restoration, flooding, hydrology, fundamental niche, hydrophyte

\section{INTRODUCTION}

Much of the literature in wetland research is focused on how hydrologic regimes affect the structure and function of a given wetland (Spence 1982, Gerritsen and Greening 1989, van der Valk et al. 1994, Barendregt et al. 1995, Owen 1995, Busch et al. 1998, Moore et al 1999, Keddy and Fraser 2000, Baldwin et al. 2001, Johnson et al. 2004). Laboratory, field, and modeling techniques have all been employed to gain insight into the processes that determine how abiotic factors contribute to wetland plant community structure (van der Valk et al. 1994, Ellison and Bedford 1995, Weiher and Keddy 1995, Casanova and Brock 2000, Cole and Brooks 2000, Baldwin et al. 2001, De Steven and Toner 2004, Johnson et al. 2004). Of all potential abiotic factors, hydrologic regimes have generally been shown to correlate most strongly with vegetation type (Keddy 2000, De Steven and Toner 2004).
Changes in land use have resulted in destruction and fragmentation of wetlands in North America over the past century, which has affected water quality, water recharge, and wildlife habitat. As a result, wetland restoration has recently become a common and widespread activity. Wetland restoration research has focused primarily on seed viability, seed germination, and seed-bank dynamics, as they relate to hydrology, nutrients, temperature, and time (van der Valk 1981, Keddy and Ellis 1985, Schneider and Sharitz 1986, Gerritsen and Greening 1989, Budelsky and Galatowitsch 1999, van der Valk et al. 1999, Leck 2003, Jensen 2004). Little information is available regarding how species perform, once germinated, over a range of hydrologic treatments (Weiher et al. 1996, Budelsky and Galatowitch 2000). Experiments have determined that an increase in water level generally reduces the growth and affects morphological responses of wetland plants (Coops et al. 1996, Newman et al. 1996, 
Table 1. Fourteen wetland plant species that were used in the experiment and grown at seven water depths.

\begin{tabular}{|c|c|c|c|c|}
\hline Scientific Name and Authority ${ }^{a}$ & Code & Common Name & Life Form & Life Cycle \\
\hline${ }^{1}$ Calamagrostis canadensis (Michx.) Beauv. & $\mathrm{Cc}$ & Blue-joint grass & Grass & Perennial \\
\hline${ }^{1}$ Carex lurida Wahlenb. & $\mathrm{Cl}$ & Hop sedge & Sedge & Perennial \\
\hline${ }^{1}$ Carex stipata Hudson & Cs & Sawbeak sedge & Sedge & Perennial \\
\hline${ }^{2}$ Carex tribuloides Wahlenb. & $\mathrm{Ct}$ & Bristlebract sedge & Sedge & Perennial \\
\hline${ }^{1}$ Carex vulpinoidea Michx. & $\mathrm{Cv}$ & Fox sedge & Sedge & Perennial \\
\hline${ }^{2}$ Elymus virginicus $\mathrm{L}$. & Ev & Virginia wildrye & Grass & Perennial \\
\hline${ }^{2}$ Glyceria canadensis (Michx.) Trin. & $\mathrm{Gc}$ & Rattlesnake mannagrass & Grass & Perennial \\
\hline${ }^{1}$ Lythrum salicaria $\mathrm{L}$. & Ls & Purple loosestrife & Forb & Facultative annual \\
\hline${ }^{1}$ Mimulus ringens $\mathrm{L}$. & $\mathrm{Mr}$ & Monkey flower & Forb & Facultative annual \\
\hline${ }^{1}$ Phalaris arundinacea $\mathrm{L}$. & $\mathrm{Pa}$ & Reed canarygrass & Grass & Perennial \\
\hline${ }^{1}$ Rumex orbiculatus A. Gray & Ro & Great water dock & Forb & Perennial \\
\hline${ }^{1}$ Scirpus cyperinus (L.) Kunth. & $\mathrm{Sc}$ & Woolgrass & Sedge & Perennial \\
\hline${ }^{2}$ Verbesina alternifolia (L.) Britt. & $\mathrm{Va}$ & Yellow ironweed & Forb & Perennial \\
\hline${ }^{2}$ Zizania aquatica $\mathrm{L}$ & $\mathrm{Za}$ & Annual wildrice & Grass & Annual \\
\hline
\end{tabular}

${ }^{a}$ from Crow and Hellquist (2000)

${ }^{1}$ indicates field-collected seed.

2 indicates seed that was purchased from Ernst Conservation Seeds.

Lentz and Dunson 1998, Lenssen et al. 1999, Miller and Zedler 2003); however, the number of species tested is generally less than five for each study, the waterdepth treatments tend to differ by at least $5 \mathrm{~cm}$, and the plants tested are generally not seedlings but vegetative ramets of mature plants (but see Kercher and Zedler 2004).

Wetland restorations generally involve the new establishment of a plant community, either by natural seed dispersal, introduced seeds, or planted seedlings. The establishment phase of the plant community is critical to colonization and stand development. Controlled mesocosm experiments have shown that control of water depth during the first year can significantly influence the potential for growth, mortality, and stand development in later years (Weiher and Keddy 1995, Budelsky and Galatowitsch 2000).

In natural systems, isolating an individual environmental factor's effect upon that system is nearly impossible. Using laboratory techniques, we can more clearly delineate the role of hydrology on a number of species (Fraser and Keddy 1997). Isolating the effect of water depth on a range of wetland species can reveal fundamental niche boundaries, information that can be applied to predictive models of plant establishment and wetland restoration.

The purpose of this experiment was to investigate the growth responses (measured as seedling survival and accumulated biomass) under different water depths at small $(2 \mathrm{~cm})$ increments in controlled microcosms. Although static water levels are generally not normal or realistic conditions found in natural marshes or wet meadows, we were interested in identifying the constraints of absolute water depth to initial establishment and performance of seedlings over a relatively short time period. Fourteen wetland species, representing a range of growth forms, were grown at seven static water depths, from $-6 \mathrm{~cm}$ to $+6 \mathrm{~cm}$ in $2 \mathrm{~cm}$ increments relative to the soil surface. Two-week-old seedlings were used because it is already well-established that flooding is a constraint to germination (van der Valk 1981, Keddy and Ellis 1985, Casanova and Brock 2000, Jensen 2004), but the gap in the literature regards the survivorship and growth of seedlings to water depth. The following questions were posited. (1) Does water depth affect biomass and root:shoot ratios of these wetland plants? (2) Is there a difference in seedling survivorship between water depths and between species? (3) Does biomass at different water depths differ between life forms (grass, forb, and sedge) and life cycles (perennial and annual)? (4) Does the hierarchy of growth performance remain consistent across water-depth treatments? (5) Do non-native invasive species (Lythrum salicaria and Phalaris arundinacea) produce more biomass across the seven water depths compared to the twelve native species tested?

\section{MATERIALS AND METHODS}

Twelve species were selected to represent a broad range of plant life forms typically found in temperate eastern North American marsh and wet meadow wetlands (Crow and Hellquist 2000) that are commonly used in wetland restoration projects (Hammer 1997, Cronk and Fennessy 2001) (Table 1). In addition, we included two invasives, Lythrum salicaria (purple loosestrife, a facultative annual forb) and Phalaris arundinacea (reed canary grass, a perennial grass), commonly found throughout North America (Apfelbaum and Sams 1987, Thompson et al. 1987). Species 
represent three life forms (forbs, sedges, and grasses) and two life cycles (facultative or obligate annuals and perennials). Seeds were either purchased through Ernst Seed Company (Meadville, PA) or collected in the field. The seed source from Ernst Seed Company is a combination of field-collected and cultivated plants that are bulk processed so that there is genetic variability. Field-collected seed were taken from multiple individuals and from at least three sites, which were then combined by species.

Seven water-depth treatments were created to test the individual effect of hydrologic regimes on the fourteen species. The hydrologic treatments were $-6,-4$, $-2,0,+2,+4$, and $+6 \mathrm{~cm}$ relative to the substrate. Species were tested individually over the seven hydrologic treatments, resulting in a $14 \times 7$ factorial design with five replicates of each water depth, yielding 490 individual microcosms. The microcosm consisted of an outer 700-mL cup with holes drilled at the appropriate water depth $(-6,-4,-2,0,+2,+4$, and +6 $\mathrm{cm}$ ) and an inner 300-mL cup filled with a 3:1 peat and sand mixture in which the plant was grown. The 300-mL cup was $10 \mathrm{~cm}$ in height; therefore, the distance of the water level to the bottom of the cup were $4,6,8,10,12,14$, and $16 \mathrm{~cm}$ from lowest to highest water depth. Holes were drilled at the bottom of the inner 300-mL cup for water uptake.

A set of fourteen microcosms was placed on a single tray, representing the fourteen plant species at one of the seven water depths. Since each water-depth treatment had five replicates, there were a total of 35 trays. The arrangement of trays and microcosm position on each tray were randomized at the beginning of the experiment.

\section{Germination}

The microcosms were seeded on March 22 and 23, 2001 with approximately ten seeds per microcosm. Seeds of each species were also placed in petri dishes filled with peat to act as a reserve for microcosms with no germination. The seeds in all microcosms were kept moist and partially covered with plastic to encourage germination. Following germination within microcosms, only one healthy seedling was kept, and the remaining seedlings and seeds were removed. If no germination was noted in a microcosm, germinated seeds from the petri dishes were transplanted into the appropriate microcosm. The timing of germination was relatively uniform within species so that we could randomly select a cohort of 2 -week-old individuals, separated by no more than 24 hours at germination. Water-depth treatments were started two weeks after germination. There was a large discrepancy between species relating to germination date, but no more than two months separated the first and last species.

\section{Standardized Conditions}

In order to isolate the effects of the water-depth treatment on the fourteen species better, other abiotic factors were standardized. A daily, 14-hour photoperiod was provided by four 1000 watt, High Pressure Sodium bulbs providing an average photosynthetically active radiation (measured with a LiCor LI-250 light meter) of $150.5 \mu \mathrm{mol} \mathrm{s}{ }^{-1} \mathrm{~m}^{-2}( \pm 8.2 \mathrm{SD}$ ) on the experimental plants. Windows in the room were covered to prevent incident solar radiation. Temperature ranged between 20 and $24^{\circ} \mathrm{C}$ and was maintained by air-conditioner units. Humidity ranged between 40 and $50 \%$ and was self-maintained due to the evaporation of the water from all the microcosms. After the initial two weeks of germination, plants were watered once per day. A watering wand was used to apply water to the outer sleeve of each individual microcosm. A bi-weekly nutrient regime of $20 \mathrm{ml}$ of full-strength Rorison's solution (Hendry and Grime 1993), containing 1.12 $\mathrm{mg}$ of nitrogen and $0.62 \mathrm{mg}$ of phosphorous, was administered into each microcosm for the duration of the experiment. Algae grew in some of the flooded microcosms but were physically removed immediately so that algae were never present longer than 24 hours.

\section{Harvesting, Drying, and Weighing}

Plants were harvested after six months of growth. Since the last species cohort germinated two months later than the first species cohort, the whole experiment ran for approximately eight months. Each plant's biomass was divided into aboveground and belowground biomass, placed in a drying oven for 48 hours at $80^{\circ} \mathrm{C}$, and weighed to the nearest ten-thousandth gram. Dead plants were scored as having zero biomass.

\section{Statistical Analyses}

A two-way, fixed-effects ANOVA was conducted for the combined wetland species by water-depth-treatment effect on total biomass. Tukey's LSD test was run to determine statistical significance between means. Biomass data were square-root transformed to improve homoscedasticity and normality of residuals. A general, non-linear modeling procedure was used to test for the combined effects of wetland species and water depth on root:shoot ratios, with dead plants excluded from the analysis. A logarithmic transformation was applied to the ratio data. A one-way, fixed-effects ANOVA was used to test the effect of water depth on survivorship, with Tukey's LSD applied post-hoc to 
Table 2. Results of 2-way ANOVA examining the effects of plant species (Species) and the water-level treatments (Water depth) on the mean plant biomass.

\begin{tabular}{lrrrc}
\hline Source of variation & SS & Df & $F$-ratio & P \\
\hline Species & 711.335 & 13 & 18.287 & $<0.001$ \\
Water depth & 770.893 & 6 & 42.940 & $<0.001$ \\
Species $\times$ Water depth & 734.994 & 78 & 3.149 & $<0.001$ \\
Error & 1172.923 & 392 & & \\
\hline
\end{tabular}

determine statistical significance between means. Survivorship of each species across the seven water depths, and all species at each water depth, was calculated with the equation: $\mathrm{N}_{i} / \mathrm{N}_{t}$; where $\mathrm{N}_{i}$ is equal to the number of individuals collected (maximum 5) divided by $\mathrm{N}_{t}$ the total number of individuals planted per treatment (5). Survivorship data were arcsine-transformed to improve homoscedasticity and normality of the data. Two-way, fixed-effects ANOVAs were conducted to test effects of (1) combined life form (grass, forb, and sedge) and water depth, and (2) life cycle (perennial and annual) and water depth on biomass. Response variables were square-root transformed to improve homoscedasticity and normality of residuals. Kendall's test of concordance $W$ (Siegel 1956) was used to test for the degree of association in the rank order of species biomass response in the different water depths. $W$ ranges between 0 and 1 , with 1 representing total concordance. Significance of $W$ was calculated with a null hypothesis of no correlation of rankings between water-depth treatments. The general linear model, all ANOVAs, and the post-hoc analyses were conducted using Systat 8 (SPSS 1998).

\section{RESULTS}

The effects of species and water depth on plant biomass were statistically significant (Table 2). An analysis of the combined biomass of all species showed that the greatest biomass occurred at water depths between -4 and $0 \mathrm{~cm}$, with a significant decrease in biomass at lower $(-6 \mathrm{~cm})$ and higher water depths $(+2,+4,+6 \mathrm{~cm})$ (Figure 1). Of the fourteen species tested, only two species showed no significant differences in means across water depths, Elymus virginicus and Verbesina alternifolia, with mean biomass less than $1.0 \mathrm{~g}$ at each water depth, and were therefore not presented in the histograms in Figure 2. For the other twelve species, the lowest biomass was recorded at the highest water depths (i.e., under flooded conditions) (Figure 2). The mean biomass of plants at each individual water depth was below $4.0 \mathrm{~g}$ for nine out of 14 spp. However, Lythrum salicaria (one of the two "invasives" tested) had a mean biomass of greater than

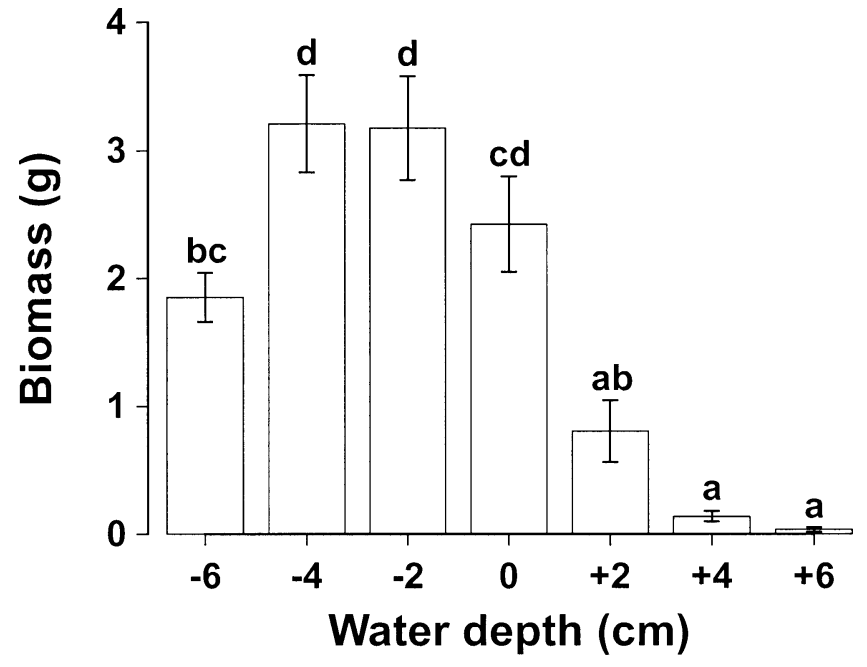

Figure 1. Effects of water depth on the mean biomass of fourteen wetland plants (see Table 1). $\mathrm{N}=490$. Error bars represent $+1 \mathrm{SE}$. Bars sharing the same letter are not significantly different using Tukey's LSD.

$4.0 \mathrm{~g}$ at $6 \mathrm{~cm}$ and greater than $6.0 \mathrm{~g}$ from -4 to +2 $\mathrm{cm}$ (Figure 2g). Phalaris arundinacea, the other "invasive," had comparatively lower growth across water depths, with a mean biomass greater than $2.0 \mathrm{~g} \mathrm{(2.375)}$ at only $-6 \mathrm{~cm}$ (Figure 2i). Other species with a mean biomass greater than $4.0 \mathrm{~g}$ included Carex lurida (Figure 2b), C. tribuloides (Figure 2d), C. vulpinoidea (Figure 2e), and Zizania aquatica (Figure 21). Although Glyceria canadensis (Figure 2f) and Mimulus ringens (Figure $2 \mathrm{~h}$ ) had significant differences in mean biomass between water-depth treatments, the differences were comparatively small, and mean biomass was never greater than $2.0 \mathrm{~g}$ across all water depths. Mimulus ringens and Lythrum salicaria were the only species to flower, and $M$. ringens flowered at all seven water-depth treatments.

There was a large variation in root:shoot ratio between species. The general linear model analyzing the effects of species and water depth on root:shoot ratio was statistically significant $\left(F_{2.305}=9.553, p<0.001\right)$, but only for species $(t=-4.350, p<0.001)$ (Figure 3 ) not for water depth $(t=1.017, p=0.310)$. Carex stipata, C. tribuloides, Lythrum salicaria, Rumex orbiculatus, and Zizania palustris had mean values close to four, but the majority had mean values below two (Figure 3). Since root:shoot ratio did not differ by water depth, no further analyses were conducted using root:shoot ratios.

Water depth affected survivorship $\left(F_{6,91}=17.083\right.$, $p<0.001)$. The highest mean percent survivorship by water depth of all species combined was found at the lowest water depths: $-6,-4,-2$, and $0 \mathrm{~cm}$ (Table 3 ). By species, survivorship ranged from 94 percent ( $\mathrm{Zi}$ zania aquatica) to 26 percent (Verbesina alternifolia), 
a)

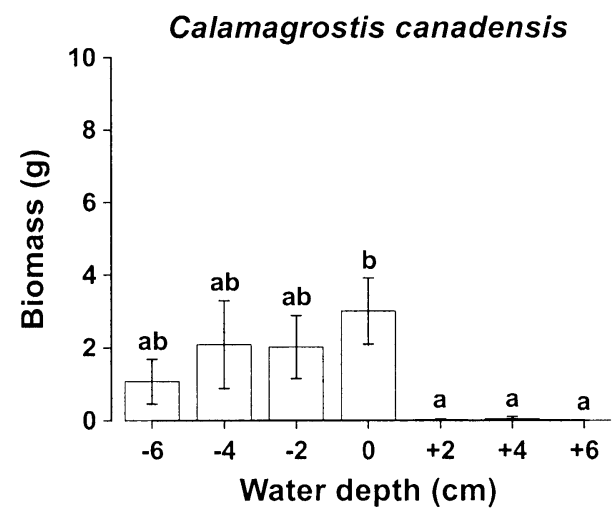

b)

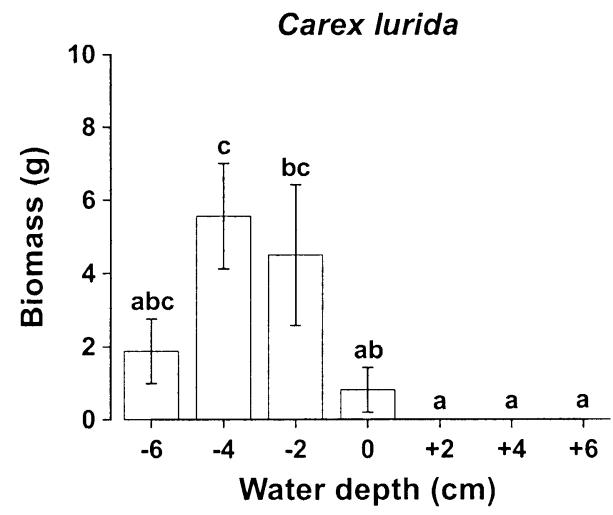

c)

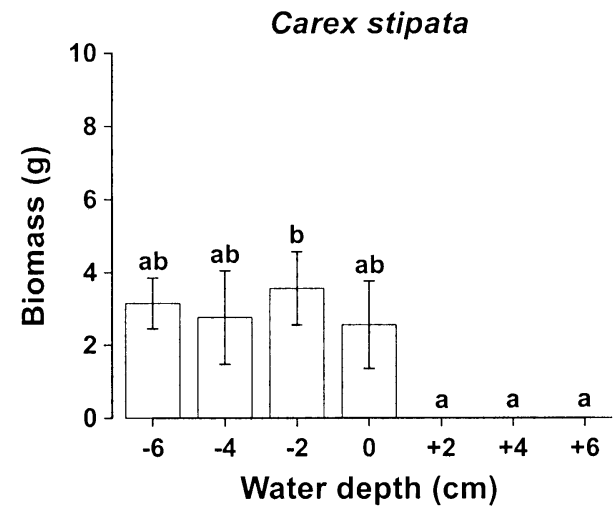

d)

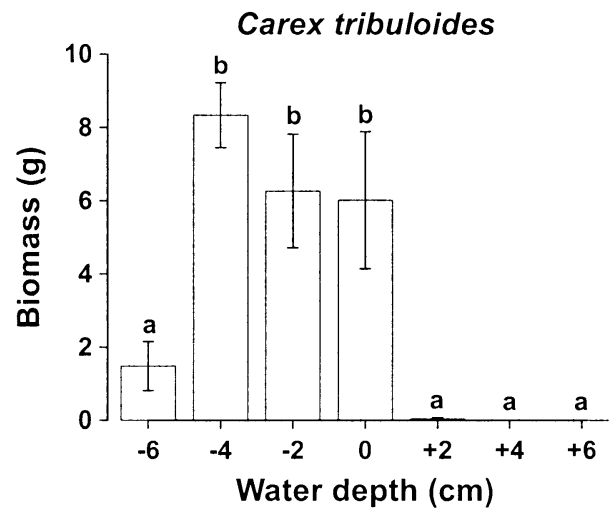

e)

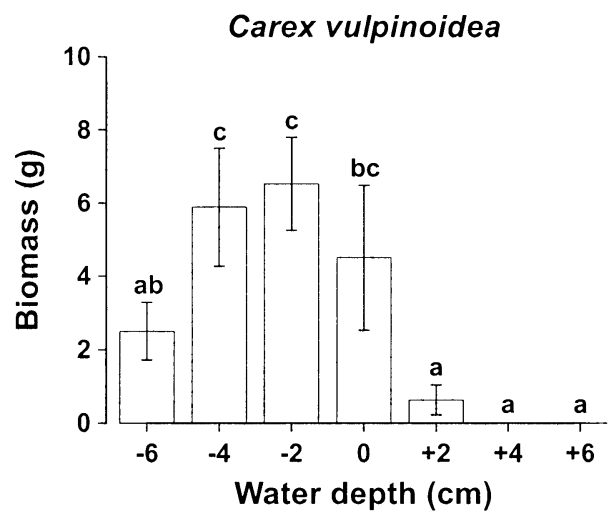

f)

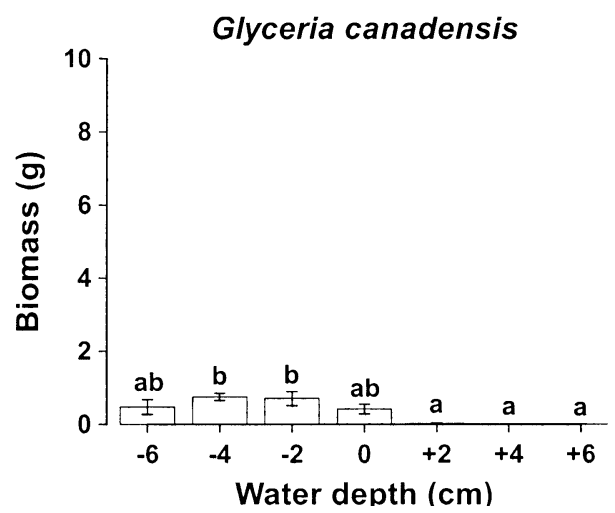

Figure 2. Effects of water depth on the mean biomass of (a) Calamagrostis canadensis, (b) Carex lurida, (c) Carex stipata, (d) Carex tribuloides, (e) Carex vulpinoidea, (f) Glyceria canadensis, (g) Lythrum salicaria, (h) Mimulus ringens, (i) Phalaris arundinacea, (j) Rumex orbiculatus, (k) Scirpus cyperinus, and (1) Zizania aquatica. Elmyus virgicus and Verbesina alternifolia are not included because the data were not significant. For each figure, $\mathrm{N}=35$. Error bars represent $+1 \mathrm{SE}$. Bars sharing the same letter are not significantly different using Tukey's LSD.

but no significant difference between species was detected. Only four species (Zizania aquatica, Elymus virginicus, Mimulus ringens, and Phalaris arundinacea) had at least one survivor across all water depths. We did not measure timing of death, but the majority of mortality in the flooded treatments occurred within the first month of the water-depth treatment.

A two-way ANOVA to determine the combined effect of life form and water depth on biomass was significant (Table 4). Sedges had the highest mean bio- 
g)

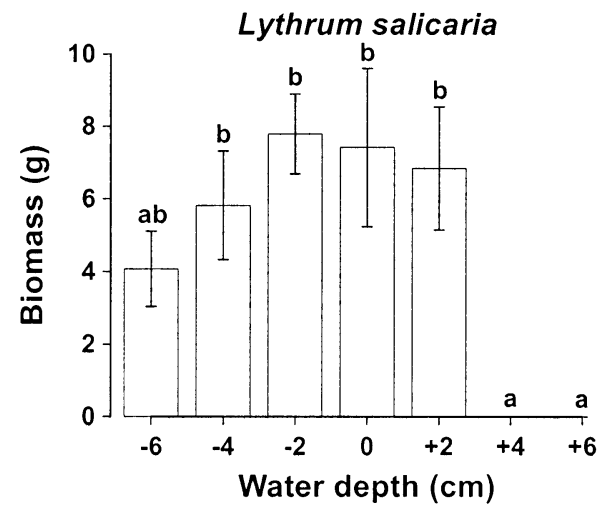

h)

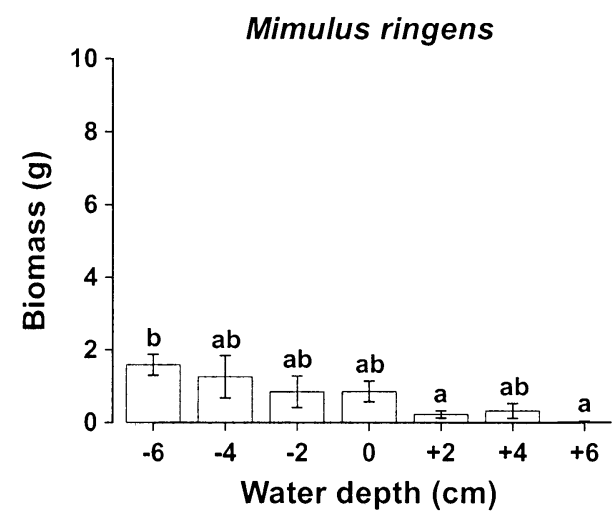

i)

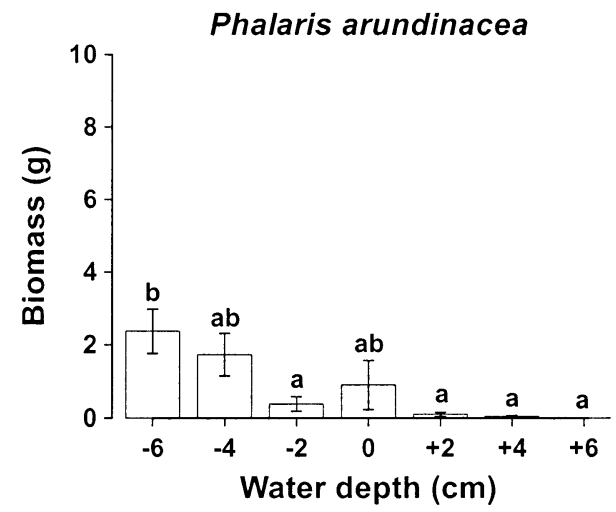

j)

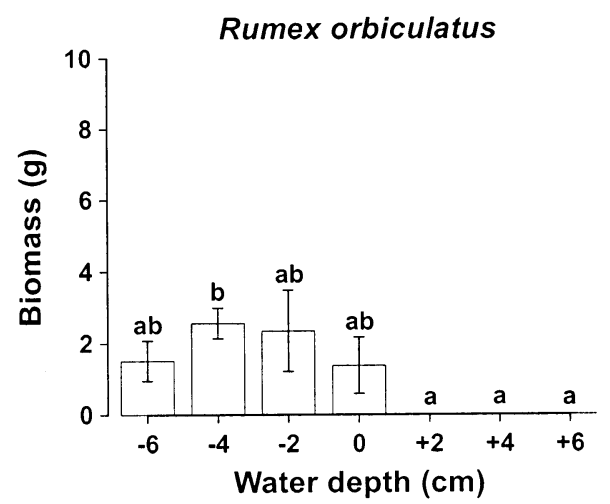

$\mathrm{k})$

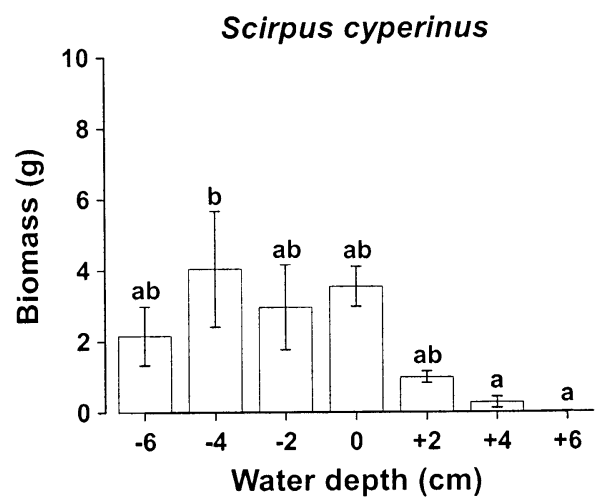

1)

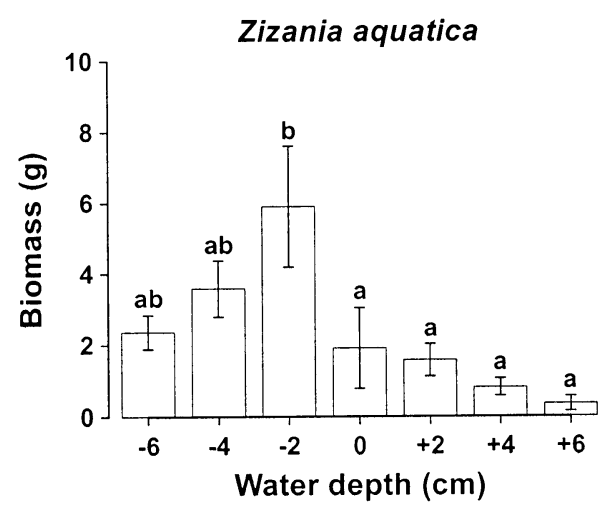

Figure 2. Continued.

mass, statistically greater than forbs and statistically greater than the grasses (Figure 4). By water depth, the mean biomass of sedges was greatest at $-6,-4$, -2 , and $0 \mathrm{~cm}$ water depth; however, the mean biomass of forbs was greatest at $+2 \mathrm{~cm}$.

A two-way ANOVA to test the combined effect of plant life cycle and water depth on biomass showed statistically significant results (Table 5). At each water depth, annuals consistently had greater mean biomass than perennials (Figure 5).
The rankings of mean biomass of the 14 species at the seven water depths had a concordance, $W$, of 0.354 $\left(\Phi_{14}=32.238 ; \mathrm{P}<0.01\right)$ (Table 6). A $W$ of 0.354 is unexpectedly low considering the results were statistically significant and therefore not independent of each other. When calculations of concordance were separated according to whether plants are grown above or below $0 \mathrm{~cm}$, the rankings below the substrate $(-6$, -4 , and $-2 \mathrm{~cm})$ had a concordance, $W$, of $0.861\left(\Phi_{14}\right.$ $=33.578 ; \mathrm{P}<0.01)$; Lythrum salicaria and Carex vul- 


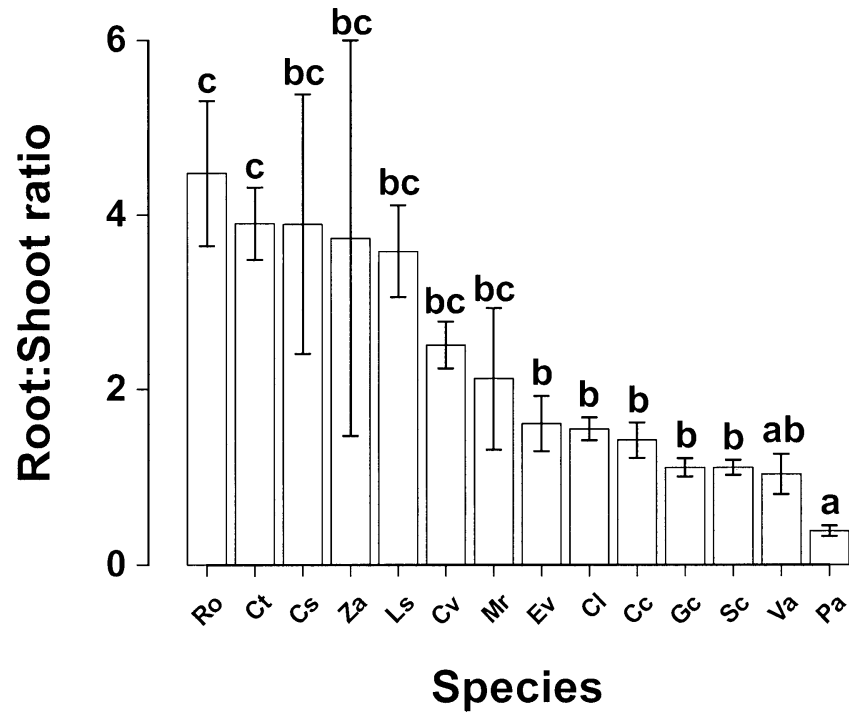

Figure 3. The mean root:shoot ratios of fourteen wetland plants (see Table 1 for species' codes). $\mathrm{N}=308$. Error bars represent +1 SE. Bars sharing the same letter are not significantly different using Tukey's LSD.

pinoidea were consistently in the top three ranking, while Elymus virginicus, Verbesina alternifolia, and Glyceria canadensis were always in the bottom three ranking. Conversely, rankings of mean biomass at the three water depths above the substrate $(+2,+4$, and $+6 \mathrm{~cm})$ had a concordance, $W$, of $0.495\left(\Phi_{14}=19.303\right.$; $\mathrm{P}>0.05)$; thus, the rankings were independent of each other.
Table 4. Results of 2-way ANOVA examining the effects of plant life form (Life form) and the water-level treatments (Water depth) on the plant biomass.

\begin{tabular}{lrrrc}
\hline \multicolumn{1}{c}{ Source of variation } & \multicolumn{1}{c}{ SS } & Df & $F$-ratio & P \\
\hline Life form & 149.938 & 2 & 15.747 & $<0.001$ \\
Water depth & 737.903 & 6 & 25.832 & $<0.001$ \\
Life form $\times$ Water depth & 236.420 & 12 & 4.138 & $<0.001$ \\
Error & 2232.893 & 469 & & \\
\hline
\end{tabular}

\section{DISCUSSION}

We asked if water depth affects survivorship and accumulated biomass of 2-week-old wetland seedlings exposed to static water-depth treatments for a period of six months. Wetland plants can tolerate periodic flooding; however, as this study demonstrates, wetland plant seedlings do not seem to be able to tolerate extended flooding. It is clear from our results that mean plant biomass and survivorship in general is strongly affected by growth at different water depths. Figure 1 could represent a typical plant physiological response curve for any number of abiotic variables of importance, where there is a maximal performance at some intermediate abiotic value (Lambers et al. 1998). Despite the relatively small standard error bars, when individual species were analyzed, there was a large difference in species' biomass response across the seven water depths. For example, two species (Elymus virgincus and Verbesina alternifolia) showed no statistical difference in biomass between water depths. How-

Table 3. Percent survivorship of each species at each water depth $(n=5)$. Far right column is the mean percent survivorship of species across all water depths. Bottom row is the mean percent survivorship of all species by water depths. Numbers sharing the same letter are not significantly different using Tukey's HSD. Values in parentheses are standard error \pm 1 .

\begin{tabular}{|c|c|c|c|c|c|c|c|c|}
\hline \multirow[b]{2}{*}{ Species } & \multicolumn{7}{|c|}{ Water Depth $(\mathrm{cm})$} & \multirow{2}{*}{$\begin{array}{c}\text { Mean } \\
\text { Survivorship } \\
\text { by Species }\end{array}$} \\
\hline & -6 & -4 & -2 & 0 & 2 & 4 & 6 & \\
\hline C. canadensis & 60 & 60 & 100 & 80 & 0 & 20 & 0 & $46(15)$ \\
\hline C. lurida & 60 & 80 & 60 & 40 & 0 & 0 & 20 & $37(12)$ \\
\hline C. stipata & 100 & 100 & 80 & 80 & 0 & 20 & 40 & $60(15)$ \\
\hline C. tribuloides & 100 & 100 & 100 & 80 & 20 & 0 & 0 & $57(18)$ \\
\hline C. vulpinoidea & 80 & 100 & 100 & 80 & 40 & 0 & 0 & $57(17)$ \\
\hline E. virginicus & 100 & 100 & 100 & 100 & 80 & 60 & 80 & $89(6)$ \\
\hline G. canadensis & 100 & 100 & 80 & 100 & 20 & 0 & 0 & $57(18)$ \\
\hline L. salicaria & 80 & 80 & 100 & 80 & 100 & 0 & 0 & $63(17)$ \\
\hline M. ringens & 100 & 80 & 60 & 100 & 60 & 80 & 40 & $74(8)$ \\
\hline$P$. arundinacea & 80 & 80 & 80 & 80 & 60 & 60 & 20 & $66(8)$ \\
\hline R. orbiculatus & 100 & 100 & 80 & 60 & 20 & 0 & 0 & $51(17)$ \\
\hline S. cyperinus & 80 & 100 & 100 & 100 & 100 & 40 & 0 & $74(15)$ \\
\hline$V$. alternifolia & 60 & 80 & 20 & 0 & 20 & 0 & 0 & $26(12)$ \\
\hline Z. aquatica & 100 & 100 & 100 & 100 & 100 & 100 & 60 & $94(6)$ \\
\hline $\begin{array}{c}\text { Mean Survivorship } \\
\text { by Water Depth }\end{array}$ & $86^{\mathrm{b}}(4)$ & $90^{\mathrm{b}}(4)$ & $83^{\mathrm{b}}(6)$ & $77^{\mathrm{b}}(8)$ & $44^{\mathrm{a}}(10)$ & $27^{\mathrm{a}}(9)$ & $19^{\mathrm{a}}(7)$ & \\
\hline
\end{tabular}




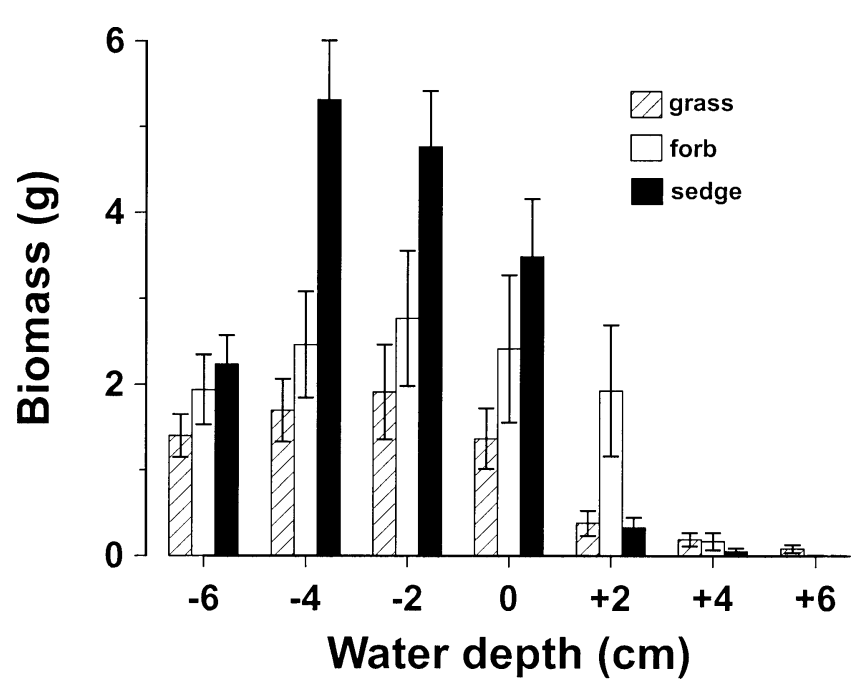

Figure 4. Effects of water depth and plant life form on the mean biomass of fourteen wetland plants (see Table 1). Error bars represent +1 SE. Bars with slanted lines are grasses, open bars are forbs, and bars with horizontal lines are sedges.

ever, the flooding treatment $(>0 \mathrm{~cm})$ generally killed plants, especially at +4 and $+6 \mathrm{~cm}$. Lythrum salicaria, Carex tribuloides, C. vulpinoidea, Leersia oryzoides, and Scirpus cyperinus all had mean biomass values above $4 \mathrm{~g}$ for at least one of the water-depth treatments between -6 and $0 \mathrm{~cm}$, but at +4 and $+6 \mathrm{~cm}$, biomass was minimal and survivorship was very low.

Unlike other studies, which have shown a decrease in root:shoot ratios with increasing water depth (Waters and Shay 1992, van den Brink et al. 1995, Coops et al. 1996, Edwards et al. 2003), we report no significant effect of water depth on root:shoot ratio. A possible explanation may be the small scale of our experiment in combination with the small differences in our water levels. The size of our microcosms probably limited the overall growth of the plants. Furthermore, species' response to microcosm size may not be in the same (linear) fashion, such that there may be differences in fine structure roots versus storage tissues belowground. The experiments noted above were in larger containers than ours, with much larger differences in water depths, and used ramets not seedlings. For example, Edwards et al. (2003) found a decrease in root:shoot ratios with an increase in water depth in Eleocharis cellulosa, but they were comparing growth response of field-collected ramets in fixed water depths of between +7 and $+54 \mathrm{~cm}$ in $3.8 \mathrm{~L}$ containers. Although we found that root:shoot ratios differed by species, there was no apparent pattern in species' response.

Not only was biomass generally reduced with an increase in water depth, but survivorship was also significantly reduced. An analysis of survivorship offers
Table 5. Results of 2-way ANOVA examining the effects of plant life cycle (Life cycle) and the water-level treatments (Water depth) on the plant biomass.

\begin{tabular}{lrrrr}
\hline \multicolumn{1}{c}{ Source of variation } & \multicolumn{1}{c}{ SS } & Df & $F$-ratio & \multicolumn{1}{c}{ P } \\
\hline Life cycle & 105.488 & 1 & 20.502 & $<0.001$ \\
Water depth & 597.159 & 6 & 19.343 & $<0.001$ \\
Life cycle $\times$ Water depth & 64.615 & 6 & 2.093 & 0.053 \\
Error & 2449.149 & 476 & & \\
\hline
\end{tabular}

interesting comparisons between species. Biomass responses of Elymus virginicus and Verbesina alternifolia at first glance appeared very similar. However, survivorship scores for each species were in stark contrast to each other, with E. virginicus scoring $89 \%$ and $V$. alternifolia scoring $26 \%$ across the seven water depths. This apparent discrepancy may be attributable to their differences in growth form. Elymus virginicus is a grass with slender blades no more than $2 \mathrm{~cm}$ wide and stems $1.5 \mathrm{~m}$ long, and $V$. alternifolia is a forb with an erect stem and leaves up to $6 \mathrm{~cm}$ wide and $12 \mathrm{~cm}$ long.

Mimulus ringens, an annual forb that can have stems up to a meter in height and leaves as large as $2 \mathrm{~cm}$ wide and $10 \mathrm{~cm}$ long, was one of only two species that produced flowers (the other was Lythrum salicaria) and the only species to produce seeds over the course of the experiment. This species was able to survive and reproduce across all seven water-depth treatments, even under flooded conditions.

The most striking aspect of all species responses across the water depths is that a $2-\mathrm{cm}$ difference in water level was sometimes the difference between

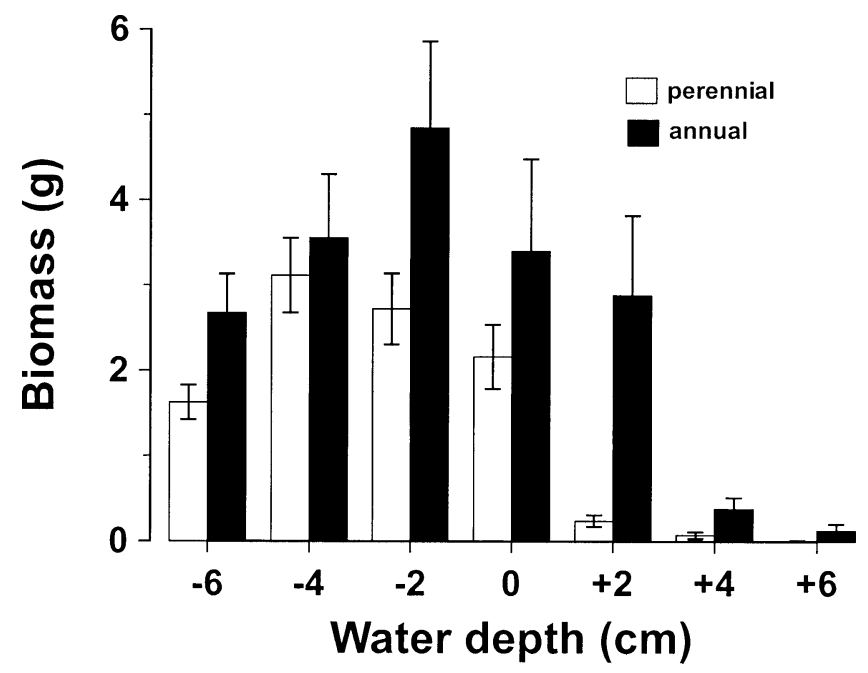

Figure 5. Effects of water depth and plant life cycle on the mean biomass of fourteen wetland plants (see Table 1). Error bars represent +1 SE. Filled bars are annuals, open bars are perennials. 
Table 6. Rank orders of decreasing biomass in fourteen species at seven different water-depth treatments. See Table 1 for species' codes.

\begin{tabular}{ccccccccccccccccc}
\hline & 1 & 2 & 3 & 4 & 5 & 6 & 7 & 8 & 9 & 10 & 11 & 12 & 13 & 14 \\
\hline \multicolumn{2}{l}{ Water depth } & $(\mathrm{cm})$ & & & & & & & & & & & & & \\
-6 & $\mathrm{Ls}$ & $\mathrm{Cs}$ & $\mathrm{Cv}$ & $\mathrm{Pa}$ & $\mathrm{Za}$ & $\mathrm{Sc}$ & $\mathrm{Cl}$ & $\mathrm{Mr}$ & $\mathrm{Ro}$ & $\mathrm{Ct}$ & $\mathrm{Cc}$ & $\mathrm{Ev}$ & $\mathrm{Va}$ & $\mathrm{Gc}$ \\
-4 & $\mathrm{Ct}$ & $\mathrm{Cv}$ & $\mathrm{Ls}$ & $\mathrm{Cl}$ & $\mathrm{Sc}$ & $\mathrm{Za}$ & $\mathrm{Cs}$ & $\mathrm{Ro}$ & $\mathrm{Cc}$ & $\mathrm{Pa}$ & $\mathrm{Mr}$ & $\mathrm{Gc}$ & $\mathrm{Ev}$ & $\mathrm{Va}$ \\
-2 & $\mathrm{Ls}$ & $\mathrm{Cv}$ & $\mathrm{Ct}$ & $\mathrm{Za}$ & $\mathrm{Cl}$ & $\mathrm{Cs}$ & $\mathrm{Sc}$ & $\mathrm{Ro}$ & $\mathrm{Cc}$ & $\mathrm{Mr}$ & $\mathrm{Gc}$ & $\mathrm{Ev}$ & $\mathrm{Pa}$ & $\mathrm{Va}$ \\
0 & $\mathrm{Ls}$ & $\mathrm{Ct}$ & $\mathrm{Cv}$ & $\mathrm{Sc}$ & $\mathrm{Cc}$ & $\mathrm{Cs}$ & $\mathrm{Za}$ & $\mathrm{Ro}$ & $\mathrm{Pa}$ & $\mathrm{Mr}$ & $\mathrm{Cl}$ & $\mathrm{Ev}$ & $\mathrm{Gc}$ & $\mathrm{Va}$ \\
2 & $\mathrm{Ls}$ & $\mathrm{Za}$ & $\mathrm{Sc}$ & $\mathrm{Cv}$ & $\mathrm{Va}$ & $\mathrm{Mr}$ & $\mathrm{Ev}$ & $\mathrm{Pa}$ & $\mathrm{Ct}$ & $\mathrm{Gc}$ & $\mathrm{Cc}$ & $\mathrm{Ro}$ & $\mathrm{Cl}$ & $\mathrm{Cs}$ \\
4 & $\mathrm{Za}$ & $\mathrm{Va}$ & $\mathrm{Ro}$ & $\mathrm{Sc}$ & $\mathrm{Cc}$ & $\mathrm{Ev}$ & $\mathrm{Mr}$ & $\mathrm{Pa}$ & $\mathrm{Cv}$ & $\mathrm{Cl}$ & $\mathrm{Cs}$ & $\mathrm{Gc}$ & $\mathrm{Ct}$ & $\mathrm{Ls}$ \\
6 & $\mathrm{Za}$ & $\mathrm{Ev}$ & $\mathrm{Mr}$ & $\mathrm{Sc}$ & $\mathrm{Cs}$ & $\mathrm{Ct}$ & $\mathrm{Pa}$ & $\mathrm{Cv}$ & $\mathrm{Ro}$ & $\mathrm{Cl}$ & $\mathrm{Va}$ & $\mathrm{Gc}$ & $\mathrm{Ls}$ & $\mathrm{Cc}$ \\
\hline
\end{tabular}

growth and senescence. Once plants had been given two weeks to establish, the water-depth treatments were initiated, leaving all plants in the flooded treatments $(>0 \mathrm{~cm}$ above soil level) partially or fully submerged. Although we initiated our treatments on twoweek-old seedlings, after six months of growth, the plants can be considered juvenile or, in the case of the flowering Lythrum salicaria and Mimulus ringens, mature. However, informal observations of all of the species in flooded conditions revealed that unless species could stay or grow above the water level, species could only maintain current growth, and most died within one month. Flooded conditions produce anaerobic soils and soils with lowered redox potential, which generates an even greater demand for oxygen within the soil (Armstrong et al. 1994, Pezeshki 2001). It seems that flooding a seedling, even though it is a wetland plant, can be considered a stress (Otte 2001). Other studies have shown that some of the same species we tested had greater biomass accumulation and survivorship in flooded treatments (e.g., Lempe et al. 2001, Miller and Zedler 2003), but these studies used ramets, not seedlings. Kercher and Zedler (2004) tested the effects of water depth on the biomass production of seventeen wetland plants at approximately three months old grown from seed, two of which we tested ( $P$. arundinacea and $C$. canadensis). The two invasives tested ( $P$. arundinacea and Typha latifolia) consistently had greater biomass accumulation than the other species (Kercher and Zedler 2004).

\section{Plant Form and Plant Life Cycle}

We separated our species by life form and life cycle in order to determine general patterns of biomass response to growth at different water depths. When grouped by life form, the sedges performed similarly in their response to water depth and generally had the largest biomass values across all water levels. The only exception was that biomass of Lythrum salicaria was greatest at $+2 \mathrm{~cm}$. Grasses, on the other hand, had the lowest biomass values across all water depths, even though survivorship was relatively high compared to the other life forms. If biomass is used as an indicator of establishment, then it seems that the sedges as a group could establish across the widest range of water levels, particularly at greater water depths. These results are in accordance with Coops et al. (1996), who compared the growth response of two grasses (Phalaris arundinacea and Phragmites australis) and two sedges (Scirpus maritimus and S. lacustris) at five different water depths $(-80,-55,-30,-5$, and +20 $\mathrm{cm})$. Kercher and Zedler (2004) also found that sedges tolerated flooding better than the broadleaf forbs. The responses reflect the zonation of life forms along the water-depth gradient: sedges in relatively deep water, forbs and grasses in shallow to very shallow water (Spence 1982, Keddy and Ellis 1985).

Our investigation of life cycle showed that annuals had much greater biomass under flooded conditions and generally had high survivorship values compared to perennials. Perhaps this is because annuals may be better able to respond to the disturbance conditions caused by flooding (Grime 1977). In fact, Mimulus ringens and L. salicaria flowered during the experiment, which therefore limited their allocation to nonreproductive shoot and root growth. Nonetheless, we only tested three annual species, compared to eleven perennials for our comparative analysis, and it is evident that $L$. salicaria strongly influenced the large biomass result for annuals. Lempe et al. (2001) also found that L. salicaria (as well as four other species from the family Lythraceae) responded to flooding by increasing growth as total plant height.

\section{Species Rank}

In order to answer whether species performed differently in relation to one another across the waterlevel treatments, a ranking of all species across all water-level treatments was created. Kendall's test of concordance showed that hierarchies remained statistically consistent across all water depths; however, the concordance value of 0.354 (where 1.0 is the highest) was 
quite low. It is clear, based on the two additional tests of concordance for the flooded $(+2,+4,+6 \mathrm{~cm})$ and non-flooded $(-6,-4,-2 \mathrm{~cm})$ water-level treatments that flooding disrupts the ranking of species response. Under non-flooded conditions, species rank was predictable, and Lythrum salicaria, a non-native invasive, was consistently ranked among the highest, by biomass, of all species. When the ranking of species' biomass was compared between the flooded conditions, there was no concordance. This reflects the distributional zonation patterns typically found on river banks and lake shores (Spence 1982). Zonation patterns develop and persist because different species have varying properties that enable them to establish, survive, and colonize at particular water depths (Keddy 1984, Grace 1987, van der Valk and Welling 1988, Keddy and Fraser 2000), and a mere 2-cm increment has the effect of disrupting the hierarchical order in the flooded treatments.

\section{Restoration Implications}

The fact that species' growth performance, measured as biomass and survival, was generally very poor in the flooded treatment $(>0 \mathrm{~cm}$ above the soil surface) has implications for restoration. Hammer (1997) stated that the watchful maintenance of hydrology in a newly restored or created wetland over the first two to three years will largely determine the level of restoration success for any given wetland. If seedlings are to be planted at a site, the result of flooding has been clearly demonstrated with this experiment. If new shoot growth is submerged, survival is reduced and growth will generally not occur. Timing of death was not measured, but we observed that the majority of mortality in the flooded treatments was within the first month. The sedge life form and the annual life cycle in our study were two general classification groups best able to tolerate prolonged flooding. Care must be taken in extrapolating these results to other species. More work is needed across a larger number of species to make general statements on the performance of life form and life cycle to growth under flooded conditions.

Our results suggest the potential use of slightly different water-level manipulations to control the growth and survivorship of the invasives Phalaris arundinacea and Lythrum salicaria. Flooding (above $0 \mathrm{~cm}$ relative to soil level) prevented the growth of the invasive $P$. arundinacea, but flooding of greater than $2 \mathrm{~cm}$ seems to be needed to prevent growth of $L$. salicaria. The life stage or age of the plant when it is flooded is probably critical because other studies have shown that both $P$. arundinacea (Miller and Zedler 2003, Kercher and Zedler 2004) and L. salicaria (Lempe et al. 2001) can tolerate flooded conditions. However, the plants in those studies were not seedlings less than one month old at the time of flooding. More work is needed to understand the relationship between the timing of flooding and the life stage of the plant.

Constructing performance indices, such as survivorship and biomass at different water depths, as in this experiment, are necessary for a better understanding of natural species distribution and abundance (Keddy 2000). Our study helps to define the fundamental niche of fourteen wetland plants with respect to water depth, which allows a predictive tool for wetland plant community establishment. However, this is a step-wise process, and other interacting abiotic and biotic variables such as fluctuating water levels (Budelsky and Galatowitsch 2000), sediment type (Lenssen et al. 1999), competition (Grace 1987), and herbivory (Sheldon 1987) need to be considered as well.

\section{ACKNOWLEDGMENTS}

We thank Adam Landaw for his help in maintaining the experiment. Randy Mitchell and Steve Weeks offered helpful comments on early versions of the manuscript. The research was supported by a U.S. Geological Survey grant through the Ohio State University Water Resources Research Institute Program to L. Fraser. Finally, this manuscript benefited greatly from the suggestions of two anonymous reviewers and Dr. Rachel Budelsky.

\section{LITERATURE CITED}

Apfelbaum, S. I. and C. E. Sams. 1987. Ecology and control of reed canarygrass (Phalaris arundinacea L.). Natural Areas Journal 7: 63-69.

Armstrong, W., R. Brandle, and M. B. Jackson. 1994. Mechanisms of flood tolerance in plants. Acta Botanica Neerlandia 43:307358.

Baldwin, A. H., M. S. Egnotovich, and E. Clarke. 2001. Hydrologic change and vegetation of tidal freshwater marshes: field, greenhouse, and seed-bank experiments. Wetlands 21:519-532.

Barendregt, A., M. J. Wassen, and P. P. Schot. 1995. Hydrological systems beyond a nature reserve, the major problem in wetland conservation of Naardermeer. Biological Conservation 72:393405.

Budelsky, R. A. and S. M. Galatowitsch. 1999. Effects of moisture, temperature, and time on seed germination of five wetland Carices: Implications for restoration. Restoration Ecology 7:86-97.

Budelsky, R. and S. M. Galatowitsch. 2000. Effects of water regime and competition on the establishment of a native sedge, Carex lacustris, in restored wetlands. Journal of Applied Ecology 37: 971-985.

Busch, D. E., W. F. Loftus, and O. L. Bass, Jr. 1998. Long-term hydrological effects on marsh plant community structure in the southern everglades. Wetlands 18:230-241.

Casanova, M. T. and M. A. Brock. 2000. How do depth, duration and frequency of flooding influence the establishment of wetland plant communities? Plant Ecology 147:237-250.

Cole, C. A. and R. P. Brooks. 2000. A comparison of the hydrologic characteristics of natural and created mainstem floodplain wetlands in Pennsylvania. Ecological Engineering 14:221-231. 
Coops, H., F. W. B. van den Brink, and G. van der Velde. 1996. Growth and morphological responses of four helophyte species in an experimental water-depth gradient. Aquatic Botany 54:11-24.

Crow, G. E. and C. B. Hellquist. 2000. Aquatic and Wetland Plants of Northeastern North America, a Revised and Enlarged Edition of Norman C. Fassett's A Manual of Aquatic Plants. Vols. 1 and 2. University of Wisconsin Press, Madison, WI, USA.

De Steven, D. and M. M. Toner. 2004. Vegetation of upper coastal plain depression wetlands: environmental templates and wetland dynamics within a landscape framework. Wetlands 24:23-42.

Edwards, A. L., D. W. Lee, and J. H. Richards. 2003. Responses to a fluctuating environment: effects of water depth on growth and biomass allocation in Eleocharis cellulosa Torr. (Cyperaceae). Canadian Journal of Botany 81:964-975.

Ellison, A. M. and B. L. Bedford. 1995. Response of a wetland vascular plant community to disturbance: a simulation study. Ecological Applications 5:109-123.

Figiel, C. R., B. Collins, and G. Wein. 1995. Variation in survival and biomass of two wetland grasses at different nutrient and water levels over a six week period. Bulletin of the Torrey Botanical Club 122:24-29.

Fraser, L. H. and P. A. Keddy. 1997. The role of experimental microcosms in ecological research. Trends in Ecology and Evolution $12: 478-481$

Gerritsen, J. and H. S. Greening. 1989. Marsh seed banks of the Okefenokee swamp: effects of hydrologic regime and nutrients. Ecology 70:750-763.

Grace, J. B. 1987. The impact of preemption on the zonation of two Typha species along lakeshores. Ecological Monographs 57:283303.

Grime, J. P. 1977. Evidence for the existence of three primary strategies in plants and its relevance to ecological and evolutionary theory. American Naturalist 111:1169-1194.

Hammer, D. A. 1997. Creating Freshwater Wetlands, second edition. Lewis Publishers, New York, NY, USA.

Hendry, G. A. F. and J. P. Grime. 1993. Methods in Comparative Plant Ecology: a Laboratory Manual. Chapman \& Hall, London, UK.

Jensen, K. 2004. Dormancy patterns, germination ecology, and seedbank types of twenty temperate fen grassland species. Wetlands 24:152-166.

Johnson, W. C., S. E. Boettcher, K. A. Poiani, and G. Guntenspergen. 2004. Influence of weather extremes on the water levels of glaciated prairie wetlands. Wetlands 24:385-398.

Keddy, P. A. 1984. Plant zonation on lakeshores in Nova Scotia: a test of the resource specialization hypothesis. Journal of Ecology 72:797-808

Keddy, P. A. 2000. Wetland Ecology: Principles and Conservation. Cambridge University Press, Cambridge, UK.

Keddy, P. A. and T. H. Ellis. 1985. Seedling recruitment of 11 wetland plant species along a water level gradient: shared or distinct responses? Canadian Journal of Botany 63:1876-1879.

Keddy, P. and L. H. Fraser. 2000. Four general principles for the management and conservation of wetlands in large lakes: the role of water levels, nutrients, competitive hierarchies and centrifugal organization. Lakes and Reservoirs: Research and Management 5: 177-185.

Kercher, S. M. and J. B. Zedler. 2004. Flood tolerance in wetland angiosperms: a comparison of invasive and noninvasive species. Aquatic Botany 80:89-102.

Lambers, H., F. S. Chapin III, and T. L. Pons. 1998. Plant Physiological Ecology. Springer-Verlag New York, NY, USA.

Leck, M. A. 2003. Seed-bank and vegetation development in a created tidal freshwater wetland on the Delaware River, Trenton, New Jersey, USA. Wetlands 23:310-343.

Lempe, J., K. J. Stevens, and R. L. Peterson. 2001. Shoot responses of six Lythraceae species to flooding. Plant Biology 2:186-193.

Lenssen, J. P. M., F. B. J. Menting, W. H. van der Putten, and C. W. P. M. Blom. 1999. Effects of sediment type and water level on biomass production of wetland plant species. Aquatic Botany 64:151-165

Lentz, K. A. and W. A. Dunson. 1998. Water level affects growth of endangered northeastern bulrush, Scirpus ancistrochaetus Schuyler. Aquatic Botany 60:213-219.

Miller, R. C. and J. B. Zedler. 2003. Responses of native and invasive wetland plants to hydroperiod and water depth. Plant Ecology 167:57-69.

Moore, H. H., W. A. Niering, L. J. Marasicano, and M. A. Dowdell. 1999. Vegetation change in created emergent wetlands (19881996) in Connecticut, U.S.A. Wetlands Ecology and Management 7:177-191

Newman, S., J. B. Grace, and J. W. Koebel. 1996. Effects of nutrients and hydroperiod on Typha, Cladium and Eleocharis: Implications for everglades restoration. Ecological Applications 6:774783.

Otte, M. L. 2001. What is stress to a wetland plant? Environmental and Experimental Botany 46:195-202.

Owen, C. R. 1995. Water budget and flow patterns in an urban wetland. Journal of Hydrology 169:171-187.

Pezeshki, S. R. 2001. Wetland plant responses to soil flooding. Environmental and Experimental Botany 46:299-312.

Schneider, R. L. and R. R. Sharitz. 1986. Seed bank dynamics in a southeastern riverine swamp. American Journal of Botany 73: 1022-1030.

Sheldon, S. P. 1987. The effects of herbivorous snails on submerged macrophyte communities in Minnesota lakes. Ecology 68:19201931.

Siegel, S. 1956. Nonparametric Statistics for the Behavioral Sciences. McGraw-Hill, New York, NY, USA.

Spence, D. H. N. 1982. The zonation of freshwater plants. Advances in Ecological Research 12:37-125.

SPSS. 1998. Systat 8.0 for Windows. Chicago, IL, USA.

Thompson, D. Q., R. L. Stuckey, and E. B. Thompson. 1987. Spread and impact and control of purple loosestrife (Lythrum salicaria) in North American wetlands. U.S. Fish and Wildlife Service Fish and Wildlife Research 2:1-55.

Tiner, R. W. 1999. Wetland Indicators: a Guide to Wetland Identification, Delineation, Classification, and Mapping. Lewis Publishers, Boca Raton, FL, USA.

van den Brink, F. W. B., G. van der Velde, W. W. Bosman, and H. Coops. 1995. Effects of substrate parameters on growth responses of eight helophyte species in relation to flooding. Aquatic Botany 50:79-97.

van der Valk, A. G. 1981. Succession in wetlands: a Gleasonian approach. Ecology 62:688-696.

van der Valk, A. G. and C. H. Welling. 1988. The development of zonation in freshwater wetlands: an experimental approach. p. 145-158. In J. H. During, M. J. A. Werger, and H. J. Willems (eds.) Diversity and Pattern in Plant Communities. Academic Publisher, The Hague, The Netherlands.

van der Valk, A. G., L. Squires, and C. H. Welling. 1994. Assessing the impacts of an increase in water level on wetland vegetation. Ecological Applications 4:535-534.

van der Valk, A. G., T. L. Bremholm, and E. Gordon. 1999. The restoration of sedge meadows. Seed viability, seed germination requirements, and seedling growth of Carex species. Wetlands 19: 756-764.

Waters, I. and J. M. Shay. 1992. Effect of water depth on population parameters of Typha glauca shoots to a water depth gradient. Canadian Journal of Botany 68:2339-2343.

Weiher, E. and P. A. Keddy. 1995. The assembly of experimental wetland plant-communities. Oikos 73:323-335.

Weiher, E., I. C. Wisheu, P. A. Keddy, and D. R. J. Moore. 1996. Establishment, persistence, and management implications of experimental wetland plant communities. Wetlands 16:208-218.

Manuscript received 1 June 2004; revisions received 1 November 2004 and 28 February 2005; accepted 4 April 2005 